\title{
Initial Growth of Pinus taeda by Fertilization Response at Planting
}

\author{
Paulo André Trazzi ${ }^{1}$ (D), Juscelina Arcanjo dos Santos², \\ Marcos Vinicius Winckler Caldeira ${ }^{1}$ (D), Diego Fernando Roters ${ }^{3}$ (D), \\ Dulcineia Carvalho ${ }^{2}$, Mário Dobner Júnior ${ }^{4}$ \\ ${ }^{1}$ Universidade Federal do Espirito Santo - UFES, Jerônimo Monteiro/ES, Brasil \\ ${ }^{2}$ Universidade Federal de Lavras - UFLA, Lavas/MG, Brasil \\ ${ }^{3}$ Universidade do Estado de Santa Catarina - UDESC, Lages/SC, Brasil \\ ${ }^{4}$ Universidade Federal de Santa Catarina - UFSC, Curitibanos/SC, Brasil
}

\begin{abstract}
The objective of this study was to evaluate how the fertilizer composition, type and application method contribute to the initial growth of Pinus taeda applied at planting. Seedlings from an open-pollinated seed orchard of Pinus taeda were planted on a Humic Dystrudepts soil containing 15 treatments of fertilizer application at planting. Basal diameter (immediately above ground - about $5 \mathrm{~cm}$ ) and total height were measured on all live plants after six, 12 and 42 months. The basal diameter at six and 12 months ranged from 0.49 to $0.63 \mathrm{~cm}$ and 1.64 to $2.15 \mathrm{~cm}$, respectively. The height at six and 12 months ranged from 0.49 to $0.64 \mathrm{~m}$ and 0.77 to $1.01 \mathrm{~m}$, respectively, indicating that fertilizing improved this characteristics in $\sim 30 \%$. Fertilizer composition, type and application method contributed to the first year of growth of Pinus taeda. Nevertheless, fertilization response disappeared after 42 months.
\end{abstract}

Keywords: loblolly pine, NPK, fertilizer, orthogonal contrast, forestry. 


\section{INTRODUCTION}

Sustainability is a moving target in forest management. Mineral fertilization must balance productivity with low costs of production and fertilizer doses should be appropriate and correctly applied (Silva et al., 2013).

To improve upon sustainable management of short-rotation plantations, especially when nutrient deficiencies are common, fertilization plans based on better knowledge on tree physiology, forest nutrition and growth characteristics are required (Alvarado, 2015).

Forest productivity is driven by the water availability and nutrient resources; then, fertilization is a tool that forest managers can use to manipulate resource availability and resources to individual trees within a stand. Fertilization increases resource availability by the direct application of limiting nutrients and influences quality and plants development in the field (Albaugh et al., 2012, 2017; Grossnickle, 2012). In addition, fertilization can compensate for decreased water availability by increasing the efficiency of stem volume production per unit of leaf area for Pinus taeda stands (Maggard et al., 2017). Fertilization regimes have been developed to enable foresters to match nutrient supply with the stand demand. Depending on the soil type, various types and amounts of fertilizer may be added (Fox et al., 2004), regarding several applications of nutrients in optimum nutrition regimes, which may further accelerate tree growth (Sullivan \& Sullivan, 2017). Pine stand fertilization has been an operational practice in the United States since the late 1960s (Everett \& Palm-Leis, 2009), and it is a common practice worldwide to mid-rotation responses to fertilization after the first or second thinning (Fox et al., 2007; Carlson et al., 2008; Campoe et al., 2010; Alzate et al., 2016; Zhao et al., 2016; Albaugh et al., 2017).

Fox et al. (2007) concluded that financial return after fertilization depends on the growth response, the cost of the fertilizer treatment, and the stumpage value of the timber produced. The internal rate of return from mid-rotation fertilization of a loblolly pine plantation with $\mathrm{N}$ and $\mathrm{P}$ would be approximately $16 \%$.

Despite of being a common practice in forest plantations, fertilization in pine stands in Brazil is not normally performed, mainly because it is believed that pine trees are not able to respond to mineral fertilizations. However, by the reduction of the production period, successive plantations, and the absence of periodic fertilization, the production sustainability of pine stands may be compromised. As the pine tree plantation in Brazil is very representative, around 1.6 million hectares in 2016 (IBA, 2017), it is necessary to research how to sustain the soil fertility to maintain or even increase the pine stands productivity. The objective of this study was to evaluate how the fertilizer composition, type and application method contribute to initial growth of Pinus taeda applied at planting.

\section{MATERIAL AND METHODS}

\subsection{Study area and experimental design}

The study was established in Rio Negrinho, Santa Catarina state, Brazil $\left(26^{\circ} 40^{\prime} \mathrm{S}\right.$ and $\left.49^{\circ} 98^{\prime} \mathrm{W}\right)$. The area is located at Primeiro Planalto Catarinense, Koppen's climate classification Cfb, Humid Subtropical zone with temperate summer (Alvares et al., 2013). Annual average precipitation is $1,700 \mathrm{~mm}$, average annual temperature is $18^{\circ} \mathrm{C}$, average minimum and maximum temperature are $13{ }^{\circ} \mathrm{C}$ and $23{ }^{\circ} \mathrm{C}$, respectively, with an average of 10 frost days annually (EPAGRI, 2009).

Seedlings from an open-pollinated seed orchards of Pinus taeda were planted on a Humic Dystrudepts soil (Souza et al., 2017), previously used under grazing by cattle. The seedlings were selected by keeping the same morphological and biometrics characteristics. Soil was prepared by a subsoiler to reduce soil compaction before planting by hand on a $2.5 \mathrm{~m} \times 2.5 \mathrm{~m}$ spacing. The chemical analysis of the soil before implementation of the experiment is described in Table 1.

A randomized complete block design was installed with eight replications containing 20 plants each plot, where 15 treatments of fertilizer application were evaluated according to Table 2. They were applied as a base fertilization in a single dose during planting. The dosages were selected according to the type (brand) recommendations.

The "mixed to soil" application method was considered by the standard form of fertilizer application, where the fertilizer was blended to the soil by a hoe after the opening of the planting hole. On the other hand, "in contact to the roots", the fertilizer was applied after the opening of the planting hole and was not mixed to soil, 
Table 1. Chemical and physical soil analysis before planting.

\begin{tabular}{|c|c|c|c|c|c|c|c|c|c|c|c|}
\hline Depth & $\mathrm{pH}$ & $\mathbf{P}$ & $\mathbf{K}$ & $\mathrm{Ca}$ & Mg & Al & $\mathrm{H}+\mathrm{Al}$ & CEC & Clay & Silt & Sand \\
\hline$(\mathrm{cm})$ & SMP & \multicolumn{2}{|c|}{$\mathrm{mg} \mathrm{dm}^{-3}$} & \multicolumn{5}{|c|}{$\mathrm{Cmol}_{\mathrm{c}} \mathrm{dm}^{-3}$} & \multicolumn{3}{|c|}{$\mathrm{g} \mathrm{Kg}^{-1}$} \\
\hline $0-20$ & 4.2 & 3.5 & 31 & 0.7 & 0.4 & 11.8 & 28.1 & 29.3 & 552 & 393 & 55 \\
\hline $20-40$ & 4.2 & 2.4 & 51 & 0.7 & 0.4 & 10.5 & 28.1 & 29.3 & 585 & 360 & 55 \\
\hline
\end{tabular}

$\mathrm{pH}$ in $\mathrm{CaCl}_{2}$ was determined in a 1:2.5 (v:v) soil:solution ratio; $\mathrm{K}$ and $\mathrm{P}$ were extracted with MEHLICH-1 and determined by flame photometry and spectrometry, respectively; $\mathrm{Ca}, \mathrm{Mg}$ and $\mathrm{Al}$ were extracted with $\mathrm{KCl} 1 \mathrm{~mol} \mathrm{~L}^{-1}$ and determined by spectrometry; $\mathrm{H}+\mathrm{Al}$ was estimated by the $\mathrm{pH}$ SMP method; $\mathrm{CEC}=$ cation exchange capacity - was estimated by the sums of exchangeable cations; Clay and Silt fractions were obtained by repeated gravitational sedimentation in water; Sand fraction was recovered as the sediment left.

Table 2. Treatments applied by the dose, composition type and application method at planting.

\begin{tabular}{|c|c|c|c|c|}
\hline Treatment & Dose & Composition & Type & Application \\
\hline T1 & & Control & & \multirow{7}{*}{ Mixed to soil } \\
\hline $\mathrm{T} 2$ & $50 \mathrm{~g} /$ plant & NPK 0-42-0 & A & \\
\hline T3 & $100 \mathrm{~g} /$ plant & NPK $0-42-0$ & A & \\
\hline T4 & $150 \mathrm{~g} /$ plant & NPK $0-42-0$ & A & \\
\hline T5 & $150 \mathrm{~g} /$ plant & NPK 8-20-10 & B & \\
\hline T6 & $150 \mathrm{~g} / \mathrm{plant}$ & NPK 8-20-10 & B & \\
\hline T7 & $100 \mathrm{~g} /$ plant & NPK 0-32-0 & $\mathrm{C}$ & \\
\hline T8 & $12 \mathrm{~g} /$ plant & NPK 0-23-14+ Mg, S, B & $\mathrm{D}$ & \multirow{8}{*}{ In contact to the roots } \\
\hline T9 & $18 \mathrm{~g} /$ plant & NPK 0-23-14 + Mg, S, B & $\mathrm{D}$ & \\
\hline T10 & $12 \mathrm{~g} /$ plant & $\mathrm{N}-44 \%$ & E & \\
\hline T11 & $21 \mathrm{~g} /$ plant & NPK 20-10-5 + Mg, Ca + Micro & $\mathrm{F}$ & \\
\hline T12 & $42 \mathrm{~g} /$ plant & NPK $20-10-5+\mathrm{Mg}, \mathrm{Ca}+$ Micro & $\mathrm{F}$ & \\
\hline T13 & $8 \mathrm{~g} /$ plant & NPK 16-7-15 + Mg, S, Fe & G & \\
\hline T14 & $10 \mathrm{~g} /$ plant & NPK 16-7-15+ Mg, S, Fe & G & \\
\hline T15 & $12 \mathrm{~g} /$ plant & NPK 16-7-15+Mg, S, Fe & G & \\
\hline
\end{tabular}

where the seedling was put in contact to the fertilizer by its substrate, and the hole was filled with soil.

An operational vegetation control treatment was frequently applied to plots to reduce competing vegetation, allow better access to the plants for measurements and prevent differential development of competing vegetation across the treatments.

\subsection{Measurements and statistical analysis}

Basal diameter (immediately above ground - about $5 \mathrm{~cm}$ ) and total height were measured on all live plants after six, 12 and 42 months. Surviving was measured by counting the number of live plants per plot after 42 months. Individual tree volume was estimated by the solid volume of a cone, according to Vallet et al. (2006).

Statistical analysis was performed separately for each parameter. Differences between treatments were tested using ANOVA. Normality and homogeneity of variances tests were examined by Lilliefors and Cochran tests, respectively. Post-hoc means comparisons were carried out using Tukey test. The level of significance of statistical tests throughout this study is 0.05 . All of the statistical analyses were performed using IBM SPSS 19 software package.

Aiming better answers on the influence of the used characteristics in the treatments, comparisons between the means of type and application method were also obtained by orthogonal contrasts, according to Table 3 .

\section{RESULTS AND DISCUSSION}

\subsection{First year of growth}

The evaluation at six and 12 months is important to understand the fertilization effects during the initial growth phase, during which cultural tending is unpredictable. Results showed significant differences between the treatments, evidencing the importance 
of fertilization for the initial growth of Pinus taeda (Table 4). Fertilizing at planting has little effect on site fertility, but promotes the development of a vigorous root system, which allows for continually improved growth (Alvarado, 2015).

The basal diameter at six and 12 months ranged from 0.49 to $0.63 \mathrm{~cm}$ and 1.64 to $2.15 \mathrm{~cm}$, respectively, indicating that fertilizing improved this characteristic in $\sim 30 \%$. The height at six and 12 months ranged from 0.49 to $0.64 \mathrm{~m}$ and 0.77 to $1.01 \mathrm{~m}$, respectively, also equivalent to $\sim 30 \%$ of enhanced growth.

At the two evaluation occasions, the treatments T8 and T9 presented averages of diameter and height statistically superior to most of them, at the same time that the control treatment and T10 presented the lowest means.

Several studies have demonstrated the importance of fertilization for the increase of productivity in pine plantations, most of them are fertilization by phosphorus and nitrogen (Hunter et al., 1986; Tiarks \& Haywood, 1986; Vose \& Allen, 1988; Fife \& Nambiar, 1997; Dedecek et al., 2008; Albaugh et al., 2017).

In a $\mathrm{N}$ and $\mathrm{P}$ fertilization study developed by Hunter et al. (1986) in New Zealand, the largest responses occurred in stands that had received fertilizer at an early age and were in soils poor in $\mathrm{N}$ availability such as sandy soils. In addition, Vose \& Allen (1988) reported, for an $\mathrm{N}$ deficient site, the highest volume

Table 3. Description of orthogonal contrasts used, comparing application method and fertilizer type.

\begin{tabular}{|c|c|c|}
\hline Contrast & Mean comparison & Comparison \\
\hline Y1 & $\boldsymbol{6}(\mathrm{T} 8+\ldots+\mathrm{T} 15)-\boldsymbol{8}(\mathrm{T} 2+\ldots+\mathrm{T} 7)$ & In contact to the roots vs. Mixed to soil \\
\hline $\mathrm{Y} 2$ & $\mathrm{~T} 2+\ldots+\mathrm{T} 7-6 \mathrm{~T} 1$ & Mixed to soil vs. Control \\
\hline Y3 & $\mathrm{T} 8+\ldots+\mathrm{T} 15-\boldsymbol{8} \mathrm{T} 1$ & In contact to the roots vs. Control \\
\hline Y4 & $\mathrm{T} 2+\mathrm{T} 3+\mathrm{T} 4-3 \mathrm{~T} 1$ & Type A vs. Control \\
\hline Y5 & $\mathrm{T} 5+\mathrm{T} 6-2 \mathrm{~T} 1$ & Type B vs. Control \\
\hline Y6 & $\mathrm{T} 7-\mathrm{T} 1$ & Type C vs. Control \\
\hline Y7 & $\mathrm{T} 8+\mathrm{T} 9-2 \mathrm{~T} 1$ & Type D vs. Control \\
\hline Y8 & $\mathrm{T} 10-\mathrm{T} 1$ & Type E vs. Control \\
\hline Y9 & $\mathrm{T} 11+\mathrm{T} 12-2 \mathrm{~T} 1$ & Type F vs. Control \\
\hline Y10 & $\mathrm{T} 13+\mathrm{T} 14+\mathrm{T} 15-3 \mathrm{~T} 1$ & Type G vs. Control \\
\hline
\end{tabular}

Table 4. Diameter and height averages at six and 12 months after fertilizer application at planting of Pinus taeda.

\begin{tabular}{|c|c|c|c|c|}
\hline Treatment & $\begin{array}{l}\text { Diameter } \\
\quad(\mathrm{cm}) \\
\text { six months }\end{array}$ & $\begin{array}{l}\text { Diameter } \\
(\mathrm{cm}) \\
12 \text { months }\end{array}$ & $\begin{array}{c}\text { Height } \\
(\mathbf{m}) \\
\text { six months }\end{array}$ & $\begin{array}{c}\text { Height } \\
(\mathrm{m}) \\
12 \text { months }\end{array}$ \\
\hline T1 & $0.49 \mathrm{~d}$ & $1.67 \mathrm{c}$ & $0.48 \mathrm{~d}$ & $0.80 \mathrm{c}$ \\
\hline $\mathrm{T} 2$ & $0.54 \mathrm{c}$ & $1.78 \mathrm{~b}$ & $0.52 \mathrm{~b}$ & $0.89 \mathrm{~b}$ \\
\hline T3 & $0.57 \mathrm{~b}$ & $1.85 \mathrm{~b}$ & $0.52 \mathrm{~b}$ & $0.87 \mathrm{~b}$ \\
\hline T4 & $0.56 \mathrm{~b}$ & $1.86 \mathrm{~b}$ & $0.51 \mathrm{~b}$ & $0.94 \mathrm{~b}$ \\
\hline T5 & $0.49 \mathrm{~d}$ & $1.64 \mathrm{c}$ & $0.49 c$ & $0.86 \mathrm{~b}$ \\
\hline T6 & $0.50 \mathrm{~d}$ & $1.67 \mathrm{c}$ & $0.49 \mathrm{c}$ & $0.84 \mathrm{~b}$ \\
\hline T7 & $0.52 \mathrm{c}$ & $1.89 \mathrm{~b}$ & $0.49 \mathrm{c}$ & $0.93 \mathrm{a}$ \\
\hline T8 & $0.62 \mathrm{a}$ & $2.02 \mathrm{a}$ & $0.53 \mathrm{a}$ & $0.95 \mathrm{a}$ \\
\hline T9 & $0.63 \mathrm{a}$ & $2.15 \mathrm{a}$ & $0.54 \mathrm{a}$ & $1.01 \mathrm{a}$ \\
\hline T10 & $0.50 \mathrm{~d}$ & $1.51 \mathrm{c}$ & $0.48 \mathrm{~d}$ & $0.77 \mathrm{c}$ \\
\hline T11 & $0.61 \mathrm{a}$ & $1.88 \mathrm{~b}$ & $0.53 \mathrm{a}$ & $0.91 \mathrm{~b}$ \\
\hline T12 & $0.58 \mathrm{~b}$ & $1.88 \mathrm{~b}$ & $0.53 \mathrm{a}$ & $0.90 \mathrm{~b}$ \\
\hline T13 & $0.57 \mathrm{~b}$ & $1.88 \mathrm{~b}$ & $0.52 \mathrm{~b}$ & $0.88 \mathrm{~b}$ \\
\hline T14 & $0.58 \mathrm{~b}$ & $1.85 \mathrm{~b}$ & $0.52 \mathrm{~b}$ & $0.87 \mathrm{~b}$ \\
\hline T15 & $0.57 \mathrm{~b}$ & $1.87 \mathrm{~b}$ & $0.51 \mathrm{~b}$ & $0.87 \mathrm{~b}$ \\
\hline
\end{tabular}

Averages followed by the same letter in the same column did not differ significantly at $5 \%$ probability by Tukey test. 
production for the highest application of $\mathrm{N}$ fertilizer (336 kg ha-1).

Tiarks \& Haywood (1986) observed an increase of Pinus taeda volume at age 5 years to $26 \mathrm{~m}^{3} / \mathrm{ha}$, compared to $12 \mathrm{~m}^{3} /$ ha without the treatments, when they evaluated a complete fertilizer (112 kg of nitrogen, $49 \mathrm{~kg}$ of phosphorus, and $93 \mathrm{~kg}$ of potassium per hectare) applied at planting, and control of herbaceous for the first 4 years. The fertilizer contained nitrogen, phosphorus, and potassium, but analysis of pine foliage indicates that phosphorus was the element causing the pine response to the fertilizer (Tiarks \& Haywood, 1986).

Fife \& Nambiar (1997) indicated that the amount of translocated foliar $\mathrm{N}$ within the tree increased with increasing rate of $\mathrm{N}$ application and contributed to the growth response of trees for five years after nitrogen fertilizer application.

To evaluate the influence of the site on the growth of Pinus taeda, Dedecek et al. (2008) selected eight different sites of at 22 years old stands, in Telêmaco Borba, southern Brazil. The authors concluded that the most productive sites presented higher levels of $\mathrm{K}$ and $\mathrm{P}$, higher $\mathrm{pH}$, higher base saturation and lower saturation by Al. They also stated that the water content available in the soil was the variable that best correlated with the growth of Pinus taeda.

Two levels of fertilization (none and 224 and $28 \mathrm{~kg} \mathrm{ha}^{-1}$ of elemental nitrogen and phosphorus, respectively) were applied on trees between 10 and 15 years old in an experiment elaborated by Albaugh et al. (2017).
The authors concluded that at six years after treatment, fertilizer significantly increased the diameter, stand basal area and stand volume increments.

The best fertilizer responses to treatments $\mathrm{T} 8$ and $\mathrm{T} 9$ is probably due to the best availability of nutrients because they are closer to the roots. For a better understanding, treatments were compared by using orthogonal contrasts (Table 5).

Contrasts Y1 and Y3 (comparison between "in contact to the roots" and "mixed to the soil" or "control", respectively) were significant for the diameter and height at six months, evidencing the importance of easy availability of the elements to the plant utilization. In addition, through the evaluation of contrast Y2 (comparison between "mixed to the soil" and "control"), it is seen that there were no significantly differences to diameter and height at six and 12 months, fact that could prove that the elements closer to the roots would facilitate their plant absorption during the initial growth phase.

The mobility and availability of nutrients to the plants could limit the productivity and yield of forest stands (Vadeboncoeur, 2010). Phosphorus in the soil is known as less mobile and bioavailable than other macronutrients (Hinsinger et al., 2011), and requires using effective soil management systems and fertilization practices to increase its efficiency and bioavailability (Barrow \& Debnath, 2014).

On the other hand, nitrogen in the soil is more mobile than other macronutrients. In addition, nitrogen can result in toxicity symptoms when the

Table 5. Difference between the means of comparison of the assessed orthogonal contrasts diameter (cm) and height $(\mathrm{m})$ at six and 12 months.

\begin{tabular}{|c|c|c|c|c|}
\hline Contrast & $\begin{array}{l}\text { Diameter } \\
\text { six months }\end{array}$ & $\begin{array}{l}\text { Diameter } \\
12 \text { months }\end{array}$ & $\begin{array}{c}\text { Height } \\
\text { six months }\end{array}$ & $\begin{array}{c}\text { Height } \\
12 \text { months }\end{array}$ \\
\hline Y1 & $0.45^{\star *}$ & $0.80^{\mathrm{ns}}$ & $0.14^{*}$ & $0.08^{\mathrm{ns}}$ \\
\hline Y2 & $0.21^{\mathrm{ns}}$ & $0.69^{\mathrm{ns}}$ & $0.11^{\mathrm{ns}}$ & $0.49^{\mathrm{ns}}$ \\
\hline Y3 & $0.73^{\star *}$ & $1.68^{\mathrm{ns}}$ & $0.35^{* *}$ & 0.72 * \\
\hline Y4 & $0.18^{*}$ & $0.49^{\mathrm{ns}}$ & $0.12^{* *}$ & $0.28^{\mathrm{ns}}$ \\
\hline Y5 & $0.01^{\mathrm{ns}}$ & $-0.02^{\mathrm{ns}}$ & $0.03^{\mathrm{ns}}$ & $0.08^{\mathrm{ns}}$ \\
\hline Y6 & $0.03^{\mathrm{ns}}$ & $0.22^{\mathrm{ns}}$ & $0.02^{\mathrm{ns}}$ & $0.13^{*}$ \\
\hline Y7 & $0.26^{* *}$ & $0.83^{* *}$ & $0.12^{* *}$ & $0.35^{* *}$ \\
\hline Y8 & $0.01^{\mathrm{ns}}$ & $-0.16^{\text {ns }}$ & $0.00^{\mathrm{ns}}$ & -0.03 ns \\
\hline Y9 & $0.21^{\star *}$ & $0.42^{\mathrm{ns}}$ & $0.11^{\star *}$ & $0.20^{\mathrm{ns}}$ \\
\hline Y10 & $0.24^{* *}$ & $0.59^{\mathrm{ns}}$ & $0.13^{* *}$ & $0.21^{\mathrm{ns}}$ \\
\hline
\end{tabular}

${ }^{\mathrm{ns}}=$ not significant by t-test $(\mathrm{p}>0.05) ;{ }^{*}$ significant by $\mathrm{t}$-test $(\mathrm{p}<0.05) ;{ }^{* *}$ significant by $\mathrm{t}$-test $(\mathrm{p}<0.01)$. 
dosage is higher than the one recommended (Britto \& Kronzucker, 2002). Plants at treatment T10, which presented the lowest means of diameter and height at six and 12 months, could have experienced some toxicity as the fertilizer was put in contact to the roots (Table 4). In addition, most of the applied $\mathrm{N}$ might have been taken up by the trees or leached below the rooting zone within one year after application (Fife \& Nambiar, 1997).

Contrast Y7 (comparison between "Type D, NPK 0-23-14 + Mg, S, B" and "control") showed significant results for all comparisons, indicating to be efficient to the diameter and height to the first year of growth. Contrasts Y 4 (comparison between "Type A, NPK 0-42-0" and "control"), Y9 (comparison between "Type F, NPK 20-10-5 + Mg, Ca + Micro" and "control") and Y10 (comparison between "Type G, NPK 16-7-15 + Mg, S, Fe" and "control") were statistically significant only to the diameter and height to the first six months.

\subsection{Forty-two months of growth}

There were no significant differences between treatments for diameter $(p=0.982)$, height $(p=0.991)$, individual volume $(\mathrm{p}=0.978)$ and survival $(0.107)$ after 42 months of Pinus taeda growth (Figure 1).
Plant diameter and height oscillated from $3.26 \mathrm{~cm}$ (T9) to $3.43 \mathrm{~cm}$ (T3), and $4.6 \mathrm{~m}$ (T9) to $4.91 \mathrm{~m}$ (T13), respectively. Plant individual volume and survival ranged from $1,935 \mathrm{~cm}^{3}$ (T9) to $2,271 \mathrm{~cm}^{3}$ (T13), and $95.6 \%$ (T5) to $97.5 \%$ (T3), respectively. The volume per ha estimated by individual volumes, spacing $(2.5 \mathrm{~m} \times 2.5 \mathrm{~m})$ and survivals ranged from $2.99 \mathrm{~m}^{3} / \mathrm{ha}$ (T9) to $3.5 \mathrm{~m}^{3} / \mathrm{ha}$ (T13).

Current fertilization regimes focus on maintaining $\mathrm{N}$ and P supply, although significant growth increases in the future are likely to occur from this more sophisticated management of nutrient availability (Fox et al., 2004). Yet, results have reported the efficiency of fertilizer application for pine tree stands, although most of them evaluated the influence of fertilizer application after thinning (Carlson et al., 2008; Alzate et al., 2016; Albaugh et al., 2017).

Data from 43 installations of a nitrogen and phosphorus mid-rotation fertilizer trial series established in the southeastern United States were analyzed by Carlson et al. (2008), which investigated how the diameter distribution of Pinus taeda L. stands changes. The results indicated that both the absolute growth response and the relative growth response of individual trees were greater among the largest trees.

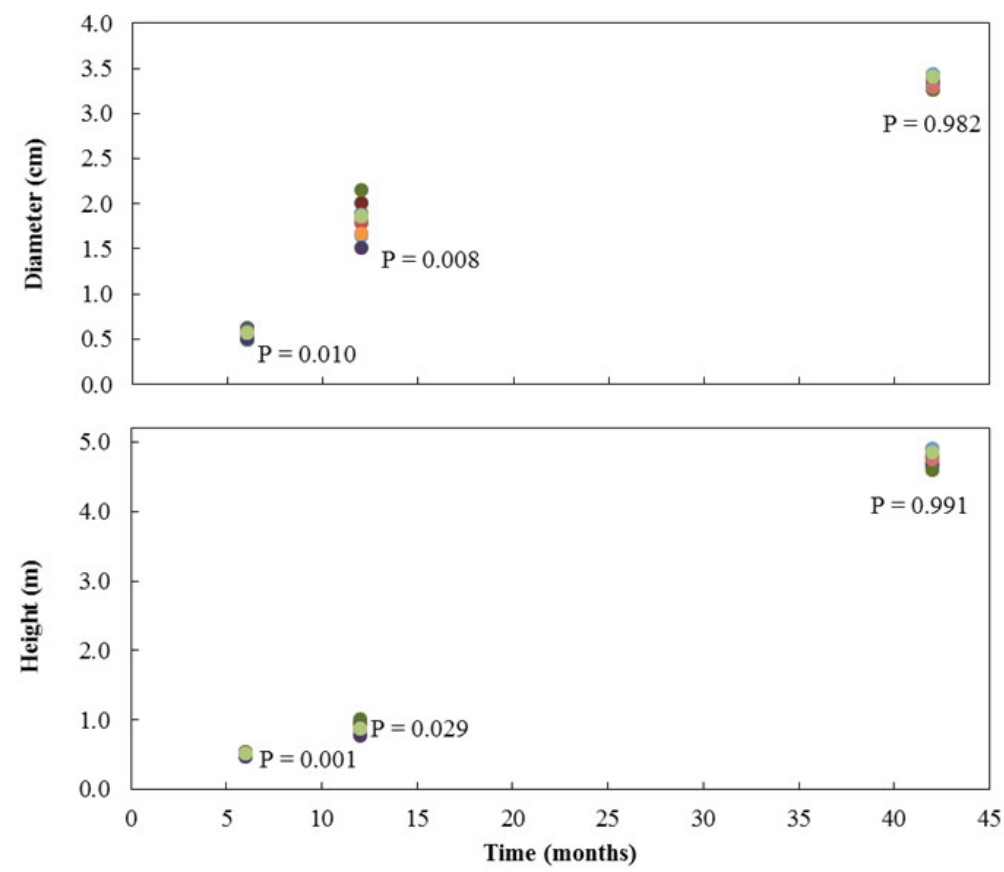

Figure 1. Diameter and height of Pinus taeda at six, 12 and 42 months after fertilizer application at planting. 
Alzate et al. (2016) assessed the effects of nitrogen (150 and $\left.300 \mathrm{~kg} \mathrm{~N} \mathrm{ha}^{-1}\right)$ and phosphorus $\left(0,20\right.$ and $\left.40 \mathrm{~kg} \mathrm{P} \mathrm{ha}^{-1}\right)$ in three mid-rotation Pinus radiata plantations after thinning at three contrasting sites. The authors found that nitrogen and phosphorus were limiting at both granitic and sandy sites, and high fertilization doses would ameliorate nutrient resource limitations and yield a cost-effective increment in stand volume.

Albaugh et al. (2017) installed a thinning and fertilization study in a 12-16 years old mid-rotation Pinus taeda L. stands in southeastern United States. The authors found that 224 and $28 \mathrm{~kg} \mathrm{ha}^{-1}$ of elemental nitrogen and phosphorus, respectively, increased diameter and stand basal area increments.

It was observed that fertilization at planting positively and significantly affected Pinus taeda growth during the first 12 months after planting. However, this enhancing effect disappeared at 42 months. Operational recommendations in this regard should consider whether the higher diameter and height growth during the first 12 months contribute, for example, to reducing tending costs. This would be an argument for recommending fertilization for Pinus taeda plantations in southern Brazil.

On the other hand, it is necessary to look further in the production period. Since fertilization showed no significant effect at 42 months of age, for maintaining the highest growth levels observed during the first 12 months, it might be necessary to keep performing fertilization periodically, before or after thinning, as widely described in the United States. Repeated fertilization regimes were recommended to enhance growth of pine plantations in the southeastern United States (Bartkowiak et al., 2015). According to Alvarado (2015), the frequency of pine fertilization depends on the natural fertility of the soils and silvicultural practices, recommending fertilization at 0,7 , and 12 years when soil fertility is high; and at $0,1,3,5,7$, and 12 years when natural soil fertility is low. As the fertility of the evaluated soil was already considered sufficient (Table 1), the plants response to fertilizers was not consistent. It is worth considering a fertilizer recommendation trial in sites of low fertility, where possibly the effect could be longer lasting and consequently efficient.

Substantial volume increase was found in young ponderosa pine plantations in northern California,
USA, by Wei et al. (2014), although these trees were fertilized four times, reinforcing the need of repeated fertilizations.

\section{CONCLUSIONS}

Fertilizer composition, type and application method contributed to the first year of growth of Pinus taeda when fertilizer was applied at planting and in contact to the roots, resulting in growth rates $\sim 30 \%$ higher than the control. Nevertheless, this enhanced growth level as a result of fertilization disappeared after 42 months.

\section{ACKNOWLEDGEMENTS}

The first author thanks to CNPQ for his Post-Doc grant.

\section{SUBMISSION STATUS}

Received: 11 sept., 2018

Accepted: 4 dec., 2018

\section{CORRESPONDENCE TO}

\section{Paulo André Trazzi}

Universidade Federal do Espirito Santo UFES, Av. Governador Lindemberg, 316, CEP 29550-000, Jerônimo Monteiro, ES, Brasil e-mail: patrazzi@gmail.com

\section{FINANCIAL SUPPORT}

Conselho Nacional de Desenvolvimento Científico e Tecnológico, (Grant / Award Number: 150073/2018-6 'Post-Doctoral Grant').

\section{REFERENCES}

Albaugh T, Stape J, Fox T, Rubilar R, Allen H. Midrotation vegetation control and fertilization response in Pinus taeda and Pinus elliottii across the southeastern United States. Southern Journal of Applied Forestry 2012; 36(1): 44-53. http://dx.doi.org/10.5849/sjaf.10-042.

Albaugh TJ, Fox TR, Rubilar RA, Cook RL, Amateis RL, Burkhart HE. Post-thinning density and fertilization affect Pinus taeda stand and individual tree growth. Forest Ecology and Management 2017; 396: 207-216. http:// dx.doi.org/10.1016/j.foreco.2017.04.030. 
Alvarado A. Plant nutrition in tropical forestry. In: Pancel L, Köhl M, editors. Tropical forestry handbook. Berlin: Springer; 2015. http://dx.doi.org/10.1007/978-3-64241554-8_105-2.

Alvares CA, Stape JL, Sentelhas PC, Gonçalves JLM, Sparovek G. Köppen's climate classification map for Brazil. Meteorologische Zeitschrift 2013; 22(6): 711-728. http:// dx.doi.org/10.1127/0941-2948/2013/0507.

Alzate MVR, Rubilar RA, Montes C, Allen HL, Fox TR, Sanfuentes E. Mid-rotation response to fertilizer by Pinus radiata D. Don at three contrasting sites. Journal of Forest Science 2016; 62(4): 153-162. http://dx.doi. org/10.17221/106/2015-JFS.

Barrow NJ, Debnath A. Effect of phosphate status on the sorption and desorption properties of some soils of northern India. Plant and Soil 2014; 378(1-2): 383-395. http://dx.doi.org/10.1007/s11104-014-2042-8.

Bartkowiak SM, Samuelson LJ, McGuire MA, Teskey RO. Fertilization increases sensitivity of canopy stomatal conductance and transpiration to throughfall reduction in an 8-year-old loblolly pine plantation. Forest Ecology and Management 2015; 354: 87-96. http://dx.doi.org/10.1016/j. foreco.2015.06.033.

Britto DT, Kronzucker HJ. $\mathrm{NH}_{4}$ toxicity in higher plants: a critical review. Journal of Plant Physiology 2002; 159(6): 567-584. http://dx.doi.org/10.1078/0176-1617-0774.

Campoe OC, Stape JL, Albaugh TJ, Lee Allen H, Fox TR, Rubilar R et al. Fertilization and irrigation effects on tree level aboveground net primary production, light interception and light use efficiency in a loblolly pine plantation. Forest Ecology and Management 2010; 288: 43-48. http://dx.doi.org/10.1016/j.foreco.2012.05.026.

Carlson CA, Burkhart HE, Allen HL, Fox TR. Absolute and relative changes in tree growth rates and changes to the stand diameter distribution of Pinus taeda as a result of midrotation fertilizer applications. Canadian Journal of Forest Research 2008; 38(7): 2063-2071. http://dx.doi. org/10.1139/X08-050.

Dedecek RA, Fier ISN, Speltz R, Lima LCS. Influência do sítio no desenvolvimento do Pinus taeda L. aos 22 anos: estado nutricional das plantas. Revista Floresta 2008; 38(2): 351-359.

Empresa de Pesquisa Agropecuária e Extensão Rural de Santa Catarina - EPAGRI. Rio Negrinho weather bureau. Florianópolis: EPAGRI; 2009. Not publised.

Everett CJ, Palm-Leis H. Availability of residual phosphorus fertilizer for loblolly pine. Forest Ecology and Management 2009; 258(10): 2207-2213. http://dx.doi.org/10.1016/j. foreco.2008.11.029.

Fife DN, Nambiar EKS. Changes in the canopy and growth of Pinus radiata in response to nitrogen supply. Forest Ecology and Management 1997; 93(1-2): 137-152. http:// dx.doi.org/10.1016/S0378-1127(96)03917-5.
Fox TR, Jokela EJ, Allen HL. Pine plantation silviculture. Asheville: U.S. Department of Agriculture, Forest Service, Southern Research Station; 2004.

Fox TR, Allen HL, Albaugh TJ, Rubilar RA, Carlson CA. Tree nutrition and forest fertilization of pine plantations in the southern United States. Southern Journal of Applied Forestry 2007; 31(1): 5-11.

Grossnickle SC. Why seedlings survive: influence of plant attributes. New Forests 2012; 43(5-6): 711-738. http:// dx.doi.org/10.1007/s11056-012-9336-6.

Hinsinger P, Brauman A, Devau N, Gérard F, Jourdan J, Laclau JP et al. Acquisition of phosphorus and other poorly mobile nutrients by roots. Where do plant nutrition models fail? Plant and Soil 2011; 348(1-2): 29-61. http:// dx.doi.org/10.1007/s11104-011-0903-y.

Hunter I, Graham J, Prince J, Nicholson G. What site factors determine the 4-year basal area response of Pinus radiata to nitrogen fertilizer. New Zealand Journal of Forestry Science 1986; 16: 30-40.

Indústria Brasileira de Árvores - IBA. Report 2017. Brasília: IBA; 2017.

Maggard A, Will RE, Wilson DS, Meek CR, Vogel JG. Fertilization can compensate for decreased water availability by increasing the efficiency of stem volume production per unit of leaf area for loblolly pine (Pinus taeda) stands. Canadian Journal of Forest Research 2017; 47(4): 445-457. http://dx.doi.org/10.1139/cjfr-2016-0422.

Silva PHM, Poggiani F, Libardi PL, Gonçalves AN. Fertilizer management of eucalypt plantations on sandy soil in Brazil: initial growth and nutrient cycling. Forest Ecology and Management 2013; 301: 67-78. http://dx.doi. org/10.1016/j.foreco.2012.10.033.

Souza VFC, Bertol I, Wolschick NH. Effects of soil management practices on water erosion under natural rainfall conditions on a Humic Dystrudept. Revista Brasileira de Ciência do Solo 2017; 41(0): 1-14. http:// dx.doi.org/10.1590/18069657rbcs20160443.

Sullivan TP, Sullivan DS. Old-growth characteristics 20 years after thinning and repeated fertilization of lodgepole pine forest: tree growth, structural attributes, and redbacked voles. Forest Ecology and Management 2017; 391: 207-220. http://dx.doi.org/10.1016/j.foreco.2017.02.021.

Tiarks AE, Haywood JD. Pinus taeda L. response to fertilization, herbaceous plant control, and woody plant control. Forest Ecology and Management 1986; 14(2): 103 112. http://dx.doi.org/10.1016/0378-1127(86)90095-2.

Vadeboncoeur MA. Meta-analysis of fertilization experiments indicates multiple limiting nutrients in northeastern deciduous forests. Canadian Journal of Forest Research 2010; 40(9): 1766-1780. http://dx.doi. org/10.1139/X10-127.

Vallet P, Dhote JF, Moguedec GL, Ravart M, Pignard G. Development of total aboveground volume equations 
for seven important forest tree species in France. Forest Ecology and Management 2006; 229(1-3): 98-110. http:// dx.doi.org/10.1016/j.foreco.2006.03.013.

Vose J, Allen H. Leaf area, stemwood growth, and nutrition relationships in loblolly pine. Forest Science 1988; 34: 547-563.

Wei L, Marshall JD, Zhang JW, Zhou H, Powers RF. 3-PG simulations of young ponderosa pine plantations under varied management intensity: why do they grow so differently? Forest Ecology and Management 2014; 313: 69-82. http://dx.doi.org/10.1016/j.foreco.2013.10.035.

Zhao D, Kane MB, Teskey RO, Fox TR, Albaugh TJ, Allen HL et al. Maximum response of loblolly pine plantations to silvicultural management in the southern United States. Forest Ecology and Management 2016; 75: 105-111. http:// dx.doi.org/10.1016/j.foreco.2016.05.035. 